\title{
Body mass of honey bee drones developing in constant and in changing temperatures
}

\author{
Krystyna CzeKońsKa, Adam TofiLsKi \\ Department of Zoology and Animal Welfare, University of Agriculture in Krakow, al. 29 Listopada 56, 31-425, Krakow, \\ Poland
}

Received 27 June 2019 - Revised 6 November 2019 - Accepted 15 January 2020

\begin{abstract}
The body mass of honey bee (Apis mellifera) drones was investigated during a post-capping development under four temperature regimes: constant low temperature $\left(32{ }^{\circ} \mathrm{C}\right)$, constant high temperature $\left(35^{\circ} \mathrm{C}\right)$, low temperature in the early stage followed by high temperature in the later stage, and high temperature in the early stage followed by low temperature in the later stage. The temperature regimes had significant influence on the drones' body mass. The heaviest drones were obtained when the temperature was high at the early stage and low at the later stage of the post-capping period. The most lightweight drones occurred at constant high temperature. The body mass of drones was changing significantly over their adult life and was highest at the age of five days. After this age, the body mass tended to decrease until the end of life. These results suggest that the highest body mass of drones can be obtained by keeping them during the post-capping development in changing and not constant temperatures.
\end{abstract}

Apis mellifera / drone / body mass / temperature / age

\section{INTRODUCTION}

One of the most important factors affecting the development of the honey bees (Apis mellifera) is precise control of temperature in the nest (Seeley 2014; Abou-Shaara et al. 2017). It is maintained in the brood area between $33{ }^{\circ} \mathrm{C}$ and $36{ }^{\circ} \mathrm{C}$ (Kleinhenz 2003; Jones and Oldroyd 2006; Seeley 2014). In the center of the nest, in a constant temperature close to $35^{\circ} \mathrm{C}$, mainly worker brood develops (Kleinhenz 2003; Seeley 2014), whereas at the nest periphery (Seeley and Morse 1976), at a lower and less precisely controlled temperatures, the drone brood tends to be reared

Corresponding author: K. Czekońska,

k.czekonska@urk.edu.pl

Manuscript editor: Peter Rosenkranz
(Levin and Collison 1990; Li et al. 2016; AbouShaara et al. 2017).

The temperature in the nest can be affected by various factors (Kronenberg and Heller 1982; Kleinhenz 2003; Jones et al. 2005; Fehler et al. 2007; Stabentheiner et al. 2010) including starvation (Jaycox 1961; Rousseau and Giovenazzo 2016), an inadequate number of workers (Fahrenholz et al. 1989; Stabentheiner et al. 2010), or diseases (Starks et al. 2000; Campbell et al. 2010). Worker brood at the post-capping stage is particularly sensitive to suboptimal temperatures (Tautz et al. 2003; Groh et al. 2004; Becher et al. 2009). Suboptimal temperature during development can affect the morphology, physiology, and behavior of adult bees (Tautz et al. 2003; Groh et al. 2004; Jones et al. 2005; Becher et al. 2009; Wang et al. 2016; Zhu et al. 2018). Workers developing in lower temperatures have deformations of their wings and other body parts, their memory and learning is impaired (Jones et al. 2005), and they suffer higher mortality 
during the larva and adult stages (Wang et al. 2016). At low temperatures, the honey bee larvae have lower metabolism, and they are more susceptible to pesticides (Medrzycki et al. 2010). Workers reared at different temperatures differ in the age of their first flight, type of food collected, tasks performed, and frequency of waggle dancing (Becher et al. 2009).

The development time of drones (24 days) is longer than in queens and workers (16 and 21 days, respectively) (Winston 1987). Over the first ten days, the drones develop in open cell. During this time larvae are progressively provisioned by workers. The final 14 days of development occur under capping (Jay 1963). During this time, prepupa and pupa do not feed, metamorphosis occurs, and the process of spermatogenesis is finished (de Oliveira and Engels 2013). Despite the fact that the drones develop more often at the nest periphery and are exposed to higher fluctuations in temperature, the influence of rearing temperature on drones is little known. Drones developing in a constant temperature of $32{ }^{\circ} \mathrm{C}$ have bigger reproductive organs, their spermatozoa are more viable, but the volume of the semen is lower in comparison with drones developing in a constant $35^{\circ} \mathrm{C}$ (Czekońska et al. 2013). Moreover, the drones developing at lower temperature are bigger and heavier (Szentgyörgyi et al. 2018; Czekońska et al. 2019).

A honey bee colony adjusts its drone production to internal (colony strength, queen presence) and external factors (time of year, food availability) (Free and Williams 1975; Wharton et al. 2007, 2008; Boes 2010; Smith et al. 2015). The colony can also affect the reproductive quality of drones (Wharton et al. 2008; Boes 2010). In unfavorable environmental conditions caused by malnutrition or low ambient temperatures, the drones can be selectively evicted from the colony (Seeley and Mikheyev 2003; Hrassnigg and Crailsheim 2005; Czekońska et al. 2015). Drones which developed in a constant higher temperature $\left(35^{\circ} \mathrm{C}\right)$ were smaller and were evicted more often in comparison with drones which developed in a lower temperature $\left(32{ }^{\circ} \mathrm{C}\right)$ (Szentgyörgyi et al. 2018; Czekońska et al. 2019). The quality of drones affects longevity and fertility of the queen (Brutscher et al. 2019; Metz and Tarpy 2019; Rangel and Fisher 2019).

The body mass of adult drones decreases with age (Gençer and Firatli 2005; Metz and Tarpy
2019). This phenomenon is independent of many environmental factors including rearing conditions (Gençer and Firatli 2005) and caging (Mazeed and Mohanny 2010). However, it is not clear if rearing temperature affects the changes in body mass during adult life. We expected that differences in body mass at emergence can be compensated for during later life. It is also not clear how changes of the temperatures during the post-capping period affect the drones. In earlier studies, it was demonstrated that during the first four days of the post-capping period, the honey bees are particularly susceptible to suboptimal temperatures (Wang et al. 2016; Zhu et al. 2018).

In this study, we verify how the temperature during the capped brood stage affects the body mass of drones. We have determined not only the body mass at emergence but also the changes of the mass during adult life. We have used four temperature regimes: constant low $\left(32^{\circ} \mathrm{C}\right)$ temperature, constant high $\left(35^{\circ} \mathrm{C}\right)$ temperature, low temperature in the early stage followed by high temperature in the later stage, and high temperature in the early stage followed by low temperature in the later stage.

\section{MATERIAL AND METHODS}

The research was conducted in Garlica Murowana near Krakow, Poland. Four honey bee colonies were used. They were housed in hives with a Wielkopolska frame $(360 \times 260 \mathrm{~mm})$. The colonies consisted of about forty thousand workers and a naturally mated queen. In each colony the queen was caged for $24 \mathrm{~h}$ on a drone comb in a frame which can be easily divided into two parts $(180 \times$ $260 \mathrm{~mm}$ each). The drone combs were newly built on a drone comb foundation from the same serial production. The next day, the queen was caged for the same amount of time on another similar frame. The drone combs with eggs were moved above the queen excluder to the upper hive body. The combs remained there until the capping of brood (11th day of the brood development) when they were moved to the incubators. The colonies from which the brood was obtained are subsequently referred to as "maternal colonies" in order to distinguish them from colonies in which the drones were maintained as adults (subsequently referred to as "maintaining colonies"). 
In this way, we obtained from each colony four drone combs. The four combs corresponded to the four experimental groups which differed in temperature during the post-capping development. The first group (subsequently referred to as $32{ }^{\circ} \mathrm{C}$ ) was kept in temperature $32{ }^{\circ} \mathrm{C}$. The combs from the second group (subsequently referred to as $35^{\circ} \mathrm{C}$ ) were kept at temperature $35^{\circ} \mathrm{C}$. The combs from the third group (subsequently referred to as $32-35^{\circ} \mathrm{C}$ ) were kept at temperature $32^{\circ} \mathrm{C}$ for six days (between 11th and 17th day of the brood development) and later were moved to $35^{\circ} \mathrm{C}$. The combs from the fourth group (subsequently referred to as $35-32{ }^{\circ} \mathrm{C}$ ) were kept at temperature $35^{\circ} \mathrm{C}$ for six days and later were moved to $32{ }^{\circ} \mathrm{C}$. At this stage the combs were kept in four identical incubators (volume 74 1). In order to control humidity inside each incubator, there was a container with tap water (area of evaporation: $204 \mathrm{~cm}^{2}$ ).

Each comb was placed in separate cages and during the last day of development, it was inspected every hour in order to collect the newly emerged drones. The drones were weighed to the nearest $0.1 \mathrm{mg}$. The drones from each comb were placed in each of the four colonies from which the brood was obtained; however, most drones were maintained in a colony other than the maternal. In the maintaining colonies, the adult drones were kept in cages made of plywood and plastic queen excluder. Each cage was only slightly bigger than one frame $(370 \times 268 \times 77 \mathrm{~mm})$, and queen excluder was fitted on two opposing walls facing the comb. The drones were not able to leave the cage, but workers could attend to them. In each colony there were four cages corresponding to the four experimental groups. In each cage, there were 100 drones representing the four colonies ( 25 drones per colony). In total in each colony, there were 400 drones ( 25 individuals $\times 4$ colonies $\times 4$ groups).

In order to determine the changes in the body mass with age, the drones were weighed every five days (immediately after emergence and at the age of 5, 10, 15, and 20 days of adult life). Every time in each colony, 80 randomly selected drones were weighed (20 individuals $\times 4$ groups). After weighing, the drones were returned to the same colony and the same cage.

Drone mortality was compared using the G-test with the Williams' correction (Sokal and Rohlf 1981). Differences in the body mass were compared using multifactorial ANOVA in Statistica version 13 . The body mass at emergence was compared between maternal colonies, whereas body mass at different ages were compared between maintaining colonies. In each experimental group, each colony and each age group distribution of the drone body mass did not differ significantly from normal distribution (in each experimental group, each colony, and each age group Kolmogorov-Smirnov test: $P>0.05$ ).

\section{RESULTS}

Of the 1600 drones introduced to the maintaining colonies, 151 did not survive to the end of the experiment (Table I). The mortality differed significantly between groups (G-test: $\mathrm{G}_{\mathrm{adj}}=142.6 \mathrm{df}=3, P<$ $0.001)$. More drones died in groups $32{ }^{\circ} \mathrm{C}$ and $35^{\circ} \mathrm{C}$ with constant temperatures in comparison with the two other groups $32-35^{\circ} \mathrm{C}$ and $35-32{ }^{\circ} \mathrm{C}$ (Table I).

A two-way analysis of variance revealed that the temperature during the post-capping period markedly affected the body mass of the newly emerged drones (Table II, effect of temperature). The highest body mass occurred in drones from group $35-32{ }^{\circ} \mathrm{C}$ (Figure 1). In three of the maternal colonies, the lowest body mass occurred in group $35^{\circ} \mathrm{C}$ (Figure 1). There were also significant differences in the body mass of drones between maternal colonies from which they originated (Table II, effect of colony). Moreover, there were significant interactions between the two factors (Table II, effect of temperature*colony) which mainly reflect the different reactions of the colonies to temperature $32-35{ }^{\circ} \mathrm{C}$. When this group was removed from the analysis, the effect

Table I. Influence of temperature during the postcapping period on the mortality of drones in maintaining colonies. Different letters indicate significant differences in pair-wise comparisons using the G-test

\begin{tabular}{lll}
\hline Temperature & Total number & Dead/missing (percent) \\
\hline $32{ }^{\circ} \mathrm{C}$ & 400 & $41(10.3 \%) \mathrm{b}$ \\
$32{ }^{\circ} \mathrm{C}-35^{\circ} \mathrm{C}$ & 400 & $13(3.3 \%) \mathrm{a}$ \\
$35^{\circ} \mathrm{C}$ & 400 & $88(22.0 \%) \mathrm{c}$ \\
$35^{\circ} \mathrm{C}-32{ }^{\circ} \mathrm{C}$ & 400 & $9(2.3 \%) \mathrm{a}$ \\
\hline
\end{tabular}


Table II. Influence of rearing temperature and maternal colonies on the body mass at the emergence of drones analyzed using multifactorial ANOVA

\begin{tabular}{llll}
\hline Effect & Df & F & P \\
\hline Temperature & 3 & 19.932 & $<0.001$ \\
Colony & 3 & 38.573 & $<0.001$ \\
Temperature*colony & 9 & 5.808 & $<0.001$ \\
\hline
\end{tabular}

of temperature and colony remained highly significant, but the interaction was not significant $(F(6,228)=1.927, P=0.077)$.

The body mass of drones changed during their lives (Figure 2, Table III, effect of age). The body mass was the highest in the fifth day of adult life. After this age, the body mass was decreasing. Multiple comparisons revealed that the body mass at the age of five days was significantly higher in comparison with all the other ages of the drones reared in all temperature regimes except $35^{\circ} \mathrm{C}$ (Table IV). In this regime increase of the body mass at the age of five days was smaller and not significantly different from the original body mass. Moreover, the body mass at later age (15 and/or 20 days) was significantly lower than the original body mass in all temperature regimes except $32{ }^{\circ} \mathrm{C}$ (Table IV). There were also significant differences in the body mass of drones between the maintaining colonies (Table III, effect of colony) and the temperatures in which they were reared (Table III, effect of temperature). There was a complicated pattern of interactions between the different factors (Table III).

\section{DISCUSSION}

In earlier studies it was demonstrated that the drones developing at a constant low temperature of $32{ }^{\circ} \mathrm{C}$ have higher body mass than those developing at a constant higher temperature of $35^{\circ} \mathrm{C}$ (Szentgyörgyi et al. 2018; Czekońska et al. 2019). The results presented here show that the drones can achieve even higher body mass when they develop during the post-capping period at temperature which changes from $35^{\circ} \mathrm{C}$ to $32^{\circ} \mathrm{C}$. On the other hand, the constant temperature of $35^{\circ} \mathrm{C}$, which is often assumed to be optimal, leads to a much lower body mass. Moreover, the drones developing in changing temperatures (from both groups $35-32{ }^{\circ} \mathrm{C}$ and $32-$ $35^{\circ} \mathrm{C}$ ) suffered lower mortality (Table I). This can be explained to some degree by higher survival of the heavier drones (Szentgyörgyi et al. 2018). It is generally believed that the workers in maintaining colonies selectively remove the drones of lower quality (Goins and Schneider 2013); therefore, it can be assumed that the drones developing in changing temperatures were of higher quality.

Both the body mass and the body size of the drones are believed to be a good predictor of their quality (Nylin and Gotthard 1998; Szentgyörgyi et al. 2016; Czekońska et al. 2019). Larger drones

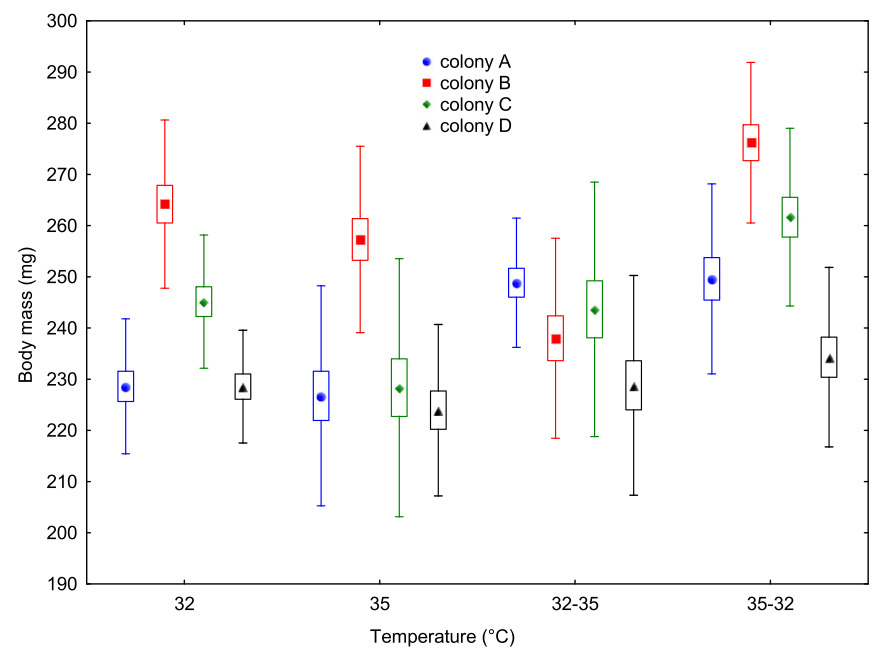

Figure 1. Mean body mass at emergence of the drones reared at different temperatures. Boxes indicate the standard errors and whiskers indicate the standard deviations. 


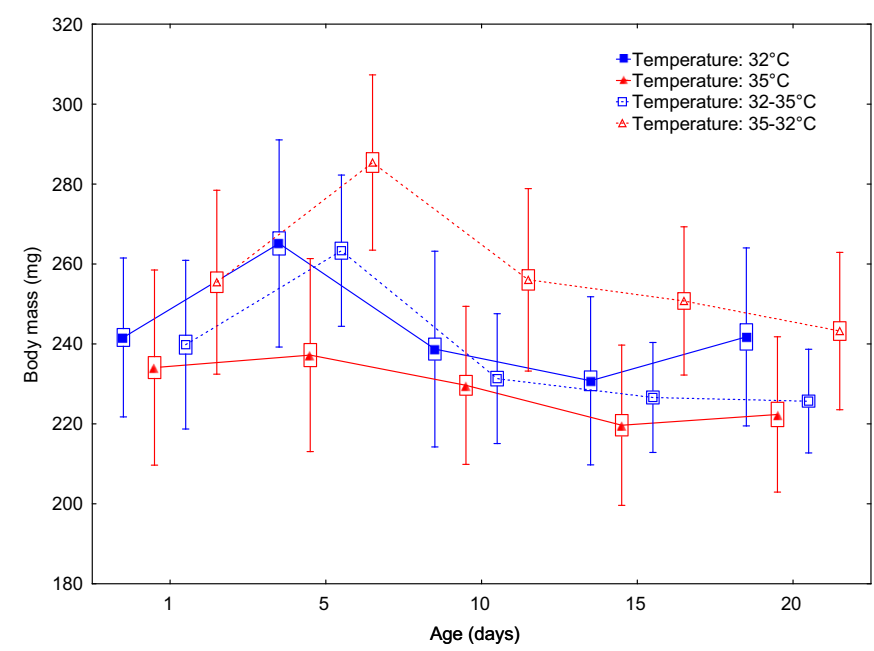

Figure 2. Changes in body mass that occur with the age of drones reared at different temperatures. Boxes indicate the standard errors and whiskers indicate the standard deviations.

produce a greater number of spermatozoa (Schlüns et al. 2003; Gençer and Firatli 2005; Taha and Alqarni 2013), start mating flights earlier (Rueppell et al. 2006), are more likely to mate with a queen (Koeniger et al. 2005; Couvillon et al. 2010; Slone et al. 2012), live longer, and their chance of surviving maturation is higher (Czekońska et al. 2019).

It is known that the honey bee colony can influence the reproductive quality of the drones (Boucher and Schneider 2009; Slone et al. 2012). Therefore, it can be assumed that the workers attempt to obtain heavier and better surviving drones by changing the rearing temperatures from higher at the earlier stage to lower in the later state of development.

In natural conditions, the drone brood is located on the edge of the nest (Seeley and Morse 1976). It is

Table III. Influence of rearing temperature, maintaining colonies, and age on the body mass of drones analyzed using multifactorial ANOVA

\begin{tabular}{llll}
\hline Effect & Df & $\mathrm{F}$ & $\mathrm{P}$ \\
\hline Temperature & 3 & 135.079 & $<0.001$ \\
Colony & 3 & 13.161 & $<0.001$ \\
Age & 4 & 111.903 & $<0.001$ \\
Temp.*colony & 9 & 3.394 & $<0.001$ \\
Age*colony & 12 & 6.749 & $<0.001$ \\
Temp.*age & 12 & 6.596 & $<0.001$ \\
Temp.*age*colony & 36 & 2.886 & $<0.001$ \\
\hline
\end{tabular}

believed that this location provides optimal conditions for the development of drones (Jaycox 1961; Jones et al. 2005). It was also demonstrated that the temperature of drone development is not only lower but also more variable in comparison with worker brood (Levin and Collison 1990; Li et al. 2016; Abou-Shaara et al. 2017). At the nest periphery, the brood temperature is more variable as it depends more on the temperature outside the nest (Kraus et al. 1998; Jones et al. 2004). The temperature fluctuations are particularly high between day and night (Kronenberg and Heller 1982). Although the diurnal temperature fluctuations of the brood are smaller in comparison to the honey stores, they can reach $1.5^{\circ} \mathrm{C}$ (Kronenberg and Heller 1982). It is possible that the larger variance of temperature of the drone development ( $\mathrm{Li}$ et al. 2016) is not related to the lower precision of control but the intentional differentiation of the temperature at different stages of the drone development. The change of rearing temperature can be difficult to achieve when the larvae of the different ages are intermixed. It is possible that the honey bee queens lay drone eggs in bunches in such a way that at any given place the drone brood is of similar age. Further studies are required to verify if this strategy of the drone brood development is present in honey bees. It is also possible that the lower temperature during the development allows the drones to achieve higher body mass, but there are other deleterious effects which outweigh the positive effects, and in consequence, 
Table IV. Significance ( $P$ values) of the differences between the body mass of drones at different ages of their lives. The drones were reared in four temperature regimes. Multiple comparisons were made using the Tukey's test. Significant differences were marked in bold

\begin{tabular}{|c|c|c|c|c|c|c|}
\hline Temperature & Age (days) & 1 & 5 & 10 & 15 & 20 \\
\hline \multirow[t]{5}{*}{$32^{\circ} \mathrm{C}$} & 1 & & $<0.0001$ & 1.0000 & 0.0722 & 1.0000 \\
\hline & 5 & $<0.0001$ & & $<0.0001$ & $<0.0001$ & $<0.0001$ \\
\hline & 10 & 1.0000 & $<0.0001$ & & 0.5781 & 1.0000 \\
\hline & 15 & 0.0722 & $<0.0001$ & 0.5781 & & 0.2399 \\
\hline & 20 & 1.0000 & $<0.0001$ & 1.0000 & 0.2399 & \\
\hline \multirow[t]{5}{*}{$35^{\circ} \mathrm{C}$} & 1 & & 1.0000 & 0.9996 & 0.0034 & 0.1713 \\
\hline & 5 & 1.0000 & & 0.7751 & 0.0001 & 0.0163 \\
\hline & 10 & 0.9986 & 0.7751 & & 0.3541 & 0.9490 \\
\hline & 15 & 0.0034 & 0.0001 & 0.3541 & & 1.0000 \\
\hline & 20 & 0.1713 & 0.0163 & 1.0000 & 1.0000 & \\
\hline \multirow[t]{5}{*}{$32-35^{\circ} \mathrm{C}$} & 1 & & $<0.0001$ & 0.3906 & 0.0047 & 0.0013 \\
\hline & 5 & $<0.0001$ & & $<0.0001$ & $<0.0001$ & $<0.0001$ \\
\hline & 10 & 0.3906 & $<0.0001$ & & 0.9954 & 0.9662 \\
\hline & 15 & 0.0047 & $<0.0001$ & 0.9954 & & 1.0000 \\
\hline & 20 & 0.0013 & $<0.0001$ & 0.9662 & 1.0000 & \\
\hline \multirow[t]{5}{*}{$35-32{ }^{\circ} \mathrm{C}$} & 1 & & $<0.0001$ & 1.0000 & 0.9946 & 0.0183 \\
\hline & 5 & $<0.0001$ & & $<0.0001$ & $<0.0001$ & $<0.0001$ \\
\hline & 10 & 1.0000 & $<0.0001$ & & 0.9790 & 0.0091 \\
\hline & 15 & 0.9946 & $<0.0001$ & 0.9790 & & 0.6877 \\
\hline & 20 & 0.0183 & $<0.0001$ & 0.0091 & 0.6877 & \\
\hline
\end{tabular}

workers maintain constant and relatively high temperature during development.

The lower temperature at the later stage of the post-capping period can be also more suitable for spermatozoa. At two days before the drone emergence, the spermatozoa are already produced and stored in the testes, which reach at that time the maximum size (Bishop 1920; de Oliveira and Engels 2013). It was shown that in the adult drones, the spermatozoa survive better at lower temperature (Stürup et al. 2013). Moreover, when the drones develop in a low temperature of $32{ }^{\circ} \mathrm{C}$, they produce fewer spermatozoa, but these are more viable (Czekońska et al. 2013).

The body mass of the drones depends not only on their development but also their environment after emergence (Szentgyörgyi et al. 2017; Czekońska et al. 2019). The factors that affect the body mass of the newly emerged drones include feeding, number of attending workers, and nest temperature (Haydak 1970; Free and Williams 1975; Hrassnigg and Crailsheim 2005; Czekońska et al. 2015; Szentgyörgyi et al. 2016). At a later age, the body mass of drones is mainly determined by the colony maintaining them and depends on its size, the presence of a queen, food availability, and health status (Wharton et al. 2007, 2008; Boes 2010; Mazeed 2011; Czekońska et al. 2019). The body mass of drones can be affected by many factors; therefore, marked differences are observed between colonies both in this and in other studies.

The body mass of the drones decreases markedly after the fifth day of life. These changes are related to maturation and occur in their testes, seminal vesicles, and mucus glands (Bishop 1920; Mazeed and Mohanny 2010; Czekońska et al. 2013; Metz and Tarpy 2019). In this study, the body mass decreased with age except for the small increase on the 20th day of life. This increase can be related to higher mortality in the smaller drones (Szentgyörgyi et al. 2018; Czekońska et al. 2019). The observed reduction of body mass coincides with the start of mating flights 
by the drones. The lower body mass allows them to spend more time in the air before returning to the nest in order to replenish the food in their crop. A similar decrease of the body mass was observed in workers at the start of foraging (Harrison 1986). It is interesting that the drones reared in different temperatures changed their body mass in different ways. It seems that the lightest drones, which were reared at $35^{\circ} \mathrm{C}$, do not increase their body mass after emergence, and their body mass loss later in life is smaller.

\section{ACKNOWLEDGMENTS}

We would like to thank Damian Głowacz for his technical assistance.

\section{AUTHOR'S CONTRIBUTIONS}

$\mathrm{KC}$ conceived this research, designed and performed experiments, participated in data analysis and preparation of the manuscript AT participated in data analysis and preparation of the manuscript.

\section{FUNDING INFORMATION}

This research was financed by the Ministry of Science and Higher Education of the Republic of Poland.

\section{OPEN ACCESS}

This article is licensed under a Creative Commons Attribution 4.0 International License, which permits use, sharing, adaptation, distribution and reproduction in any medium or format, as long as you give appropriate credit to the original author(s) and the source, provide a link to the Creative Commons licence, and indicate if changes were made. The images or other third party material in this article are included in the article's Creative Commons licence, unless indicated otherwise in a credit line to the material. If material is not included in the article's Creative Commons licence and your intended use is not permitted by statutory regulation or exceeds the permitted use, you will need to obtain permission directly from the copyright holder. To view a copy of this licence, visit http://creativecommons. org/licenses/by/4.0/.

La masse corporelle des mâles d'abeilles se développe à des températures constantes et variables.
Apis mellifera / mâle / masse corporelle / température / âge.

Körpergewicht von Honigbienen-Drohnen, die sich unter konstanten bzw.

variablen Temperaturen entwickeln.

Apis mellifera / Drohnen / Körpergewicht / Temperature / Alter.

\section{REFERENCES}

Abou-Shaara, H.F., Owayss, A.A., Ibrahim, Y.Y., Basuny, N.K. (2017) A review of impacts of temperature and relative humidity on various activities of honey bees. Insectes Sociaux. 1-9. https://doi.org/10.1007/s00040017-0573-8

Becher, M.A., Scharpenberg, H., Moritz, R.F.A. (2009) Pupal developmental temperature and behavioral specialization of honeybee workers (Apis mellifera L.). J. Comp. Physiol. A. 195, 673-679. https://doi. org/10.1007/s00359-009-0442-7

Bishop, G.H. (1920) Fertilization in the honey-bee. I. The male sexual organs: Their histological structure and physiological functioning. J. Exp. Zool. 31, 224265. https://doi.org/10.1002/jez.1400310203

Boes, K.E. (2010) Honeybee colony drone production and maintenance in accordance with environmental factors: an interplay of queen and worker decisions. Insectes Sociaux. 57, 1-9

Boucher, M., Schneider, S.S. (2009) Communication signals used in worker-drone interactions in the honeybee, Apis mellifera. Anim. Behav. 78, 247-254. https://doi.org/10.1016/j.anbehav.2009.04.019

Brutscher, L.M., Baer, B., Niño, E.L. (2019) Putative Drone Copulation Factors Regulating Honey Bee (Apis mellifera) Queen Reproduction and Health: A Review. Insects. 10, 8. https://doi.org/10.3390 /insects 10010008

Campbell, J., Kessler, B., Mayack, C., Naug, D. (2010) Behavioural fever in infected honeybees: parasitic manipulation or coincidental benefit? Parasitology. 137, 1487-1491. https://doi.org/10.1017 /S0031182010000235

Couvillon, M.J., Hughes, W.O., Perez-Sato, J.A., et al. (2010) Sexual selection in honey bees: colony variation and the importance of size in male mating success. Behav. Ecol. 21, 520-525

Czekońska, K., Chuda-Mickiewicz, B., Chorbiński, P. (2013) The effect of brood incubation temperature on the reproductive value of honey bee (Apis mellifera) drones. J. Apic. Res. 52, 96-105 
Czekońska, K., Chuda-Mickiewicz, B., Samborski, J. (2015) Quality of honeybee drones reared in colonies with limited and unlimited access to pollen. Apidologie. 46, 1-9

Czekońska, K., Szentgyörgyi, H., Tofilski, A. (2019) Body mass but not wing size or symmetry correlates with life span of honey bee drones. Bull. Entomol. Res. 109, 383-389. https://doi.org/10.1017 /S0007485318000664

de Oliveira, T.S., Engels, W. (2013) Classification of Substages in Preimaginal Development of Honey Bee Drones (Hymenoptera: Apidae). Entomol. Gen. 287293. https://doi.org/10.1127/entom.gen/34/2013/287

Fahrenholz, L., Lamprecht, I., Schricker, B. (1989) Thermal investigations of a honey bee colony: thermoregulation of the hive during summer and winter and heat production of members of different bee castes. J. Comp. Physiol. B. 159, 551-560. https://doi. org/10.1007/BF00694379

Fehler. M., Kleinhenz, M., Klügl, F., et al. (2007) Caps and gaps: a computer model for studies on brood incubation strategies in honeybees (Apis mellifera carnica). Naturwissenschaften. 94, 675-680. https://doi. org/10.1007/s00114-007-0240-4

Free, J.B., Williams, I.H. (1975) Factors determining the rearing and rejection of drones by the honeybee colony. Anim. Behav. 23, 650-675. https://doi. org/10.1016/0003-3472(75)90143-8

Gençer, H.V., Firatli, Ç. (2005) Reproductive and morphological comparisons of drones reared in queenright and laying worker colonies. J. Apic. Res. 44, 163-167

Goins, A., Schneider, S.S. (2013) Drone "quality" and caste interactions in the honey bee, Apis mellifera L. Insectes Sociaux. 60, 453-461 https://doi. org/10.1007/s00040-013-0310-x

Groh, C., Tautz, J., Rossler, W. (2004) Synaptic organization in the adult honey bee brain is influenced by brood-temperature control during pupal development. Proc. Natl. Acad. Sci. 101, 4268-4273. https://doi. org/10.1073/pnas.0400773101

Harrison, J.M. (1986) Caste-specific changes in honeybee flight capacity. Physiol. Zool. 175-187

Haydak, M.H. (1970) Honey Bee Nutrition. Annu. Rev. Entomol. 15, 143-156. https://doi.org/10.1146 /annurev.en.15.010170.001043

Hrassnigg, N., Crailsheim, K. (2005) Differences in drone and worker physiology in honeybees (Apis mellifera). Apidologie. 36, 255-277

Jay, S.C. (1963) The development of honeybees in their cells. J. Apic. Res. 2, 117-134

Jaycox, E.R. (1961) The Effects of Various Foods and Temperatures on Sexual Maturity of the Drone Honey Bee (Apis mellifera). Ann. Entomol. Soc. Am. 54, 519-523. https://doi.org/10.1093 /aesa/54.4.519

Jones, J.C., Oldroyd, B.P. (2006) Nest Thermoregulation in Social Insects. In: Simpson SJ (ed). Advances in Insect Physiology. Academic Press, pp 153-191
Jones, J.C., Myerscough, M.R., Graham, S., Oldroyd, B.P. (2004) Honey Bee Nest Thermoregulation: Diversity Promotes Stability. Science. 305 , 402-404. https://doi. org/10.1126/science. 1096340

Jones, J.C., Helliwell, P., Beekman, M., et al. (2005) The effects of rearing temperature on developmental stability and learning and memory in the honey bee, Apis mellifera. J. Comp. Physiol. A. 191, 1121-1129. https://doi.org/10.1007/s00359$005-0035-\mathrm{z}$

Kleinhenz, M. (2003) Hot bees in empty broodnest cells: heating from within. J. Exp. Biol. 206, 4217-4231. https://doi.org/10.1242/jeb.00680

Koeniger, N., Koeniger, G., Gries, M., Tingek, S. (2005) Drone competition at drone congregation areas in four Apis species. Apidologie. 36, 211-221

Kraus, B., Velthuis, H.H.W., Tingek, S. (1998) Temperature profiles of the brood nests of Apis cerana and Apis mellifera colonies and their relation to varroosis. J. Apic. Res. 37, 175-181. https://doi.org/10.1080 /00218839.1998.11100969

Kronenberg, F., Heller, H.C. (1982) Colonial thermoregulation in honey bees (Apis mellifera). J. Comp. Physiol. B. 148, 65-76. https://doi.org/10.1007 /BF00688889

Levin, C.G., Collison, C.H. (1990) Broodnest Temperature Differences and their Possible Effect on Drone Brood Production and Distribution in Honeybee Colonies. J. Apic. Res. 29, 35-44. https://doi.org/10.1080 /00218839.1990.11101195

Li, Z., Huang, Z.Y., Sharma, D.B., et al. (2016) Drone and Worker Brood Microclimates Are Regulated Differentially in Honey Bees, Apis mellifera. PLOS. ONE. 11, e0148740. https://doi.org/10.1371/journal. pone. 0148740

Mazeed, A.M. (2011) Morphometry and number of spermatozoa in drone honeybees (Hymenoptera: Apidae) reared under different conditions. Eur. J. Entomol. 108, 673

Mazeed, A.M., Mohanny, K.M. (2010) Some reproductive characteristics of honeybee drones in relation to their ages. Entomol. Res. 40, 245-250. https://doi. org/10.1111/j.1748-5967.2010.00297.x

Medrzycki, P., Sgolastra, F., Bortolotti, L., et al. (2010) Influence of brood rearing temperature on honey bee development and susceptibility to poisoning by pesticides. J. Apic. Res. 49, 52-59. https://doi.org/10.3896 /IBRA.1.49.1.07

Metz, B.N., Tarpy, D.R. (2019) Reproductive Senescence in Drones of the Honey Bee (Apis mellifera). Insects. 10, 11. https://doi.org/10.3390/insects10010011

Nylin, S., Gotthard, K. (1998) Plasticity in Life-History Traits. Annu. Rev. Entomol. 43, 63-83. https://doi. org/10.1146/annurev.ento.43.1.63

Rangel, J., Fisher, A. (2019) Factors affecting the reproductive health of honey bee (Apis mellifera) drones-a review. Apidologie. https://doi.org/10.1007/s13592019-00684-X 
Rousseau, A., Giovenazzo, P. (2016) Optimizing Drone Fertility With Spring Nutritional Supplements to Honey Bee (Hymenoptera: Apidae) Colonies. J. Econ. Entomol. 109, 1009-1014. https://doi.org/10.1093 /jee/tow056

Rueppell, O., Page, R.E., Fondrk, M.K. (2006) Male behavioural maturation rate responds to selection on pollen hoarding in honeybees. Anim. Behav. 71, 227-234

Schlüns, H., Schlüns, E., Van Praagh, J., Moritz, R. (2003) Sperm numbers in drone honeybees (Apis mellifera) depend on body size. Apidologie. 34, 577-584

Seeley, T.D. (2014) Honeybee Ecology: A Study of Adaptation in Social Life. Princeton University Press

Seeley, T.D., Mikheyev, A.S. (2003) Reproductive decisions by honey bee colonies: tuning investment in male production in relation to success in energy acquisition. Insectes Sociaux. 50, 134-138. https://doi. org/10.1007/s00040-003-0638-8

Seeley, T.D., Morse, R.A. (1976) The nest of the honey bee (Apis mellifera L.). Insectes Sociaux. 23, 495-512. https://doi.org/10.1007/BF02223477

Slone, J.D., Stout, T.L., Huang, Z.Y., Schneider, S.S. (2012) The influence of drone physical condition on the likelihood of receiving vibration signals from worker honey bees, Apis mellifera. Insectes Sociaux. 59, 101-107

Smith, M.L., Ostwald, M.M., Seeley, T.D. (2015) Adaptive tuning of an extended phenotype: honeybees seasonally shift their honey storage to optimize male production. Anim. Behav. 103, 29-33. https://doi. org/10.1016/j.anbehav.2015.01.035

Sokal, R.R., Rohlf, F.J. (1981) Biometry: the principles and practice of statistics in biological research, 2nd. San Francisco: W.H. Freeman

Stabentheiner, A., Kovac, H., Brodschneider, R. (2010) Honeybee Colony Thermoregulation - Regulatory Mechanisms and Contribution of Individuals in Dependence on Age, Location and Thermal Stress. PLoS ONE. 5, e8967. https://doi.org/10.1371/journal. pone. 0008967

Starks, P.T., Blackie, C.A., Seeley, T.D. (2000) Fever in honeybee colonies. Naturwissenschaften. 87, 229231. https://doi.org/10.1007/s001140050709

Stürup, M., Baer-Imhoof, B., Nash, D.R., et al. (2013) When every sperm counts: factors affecting male fertility in the honeybee Apis mellifera. Behav. Ecol. 24, 1192-1198. https://doi.org/10.1093/beheco/art049
Szentgyörgyi, H., Czekońska, K., Tofilski, A. (2016) Influence of pollen deprivation on the fore wing asymmetry of honeybee workers and drones. Apidologie. 47, 653-662. https://doi.org/10.1007 /s13592-015-0415-5

Szentgyörgyi, H., Czekońska, K., Tofilski, A. (2017) The Effects of Starvation of Honey Bee Larvae on Reproductive Quality and Wing Asymmetry of Honey Bee Drones. J. Apic. Sci. 61, 233-243. https://doi. org/10.1515/jas-2017-0018

Szentgyörgyi, H., Czekońska, K., Tofilski. A. (2018) Honey bees are larger and live longer after developing at low temperature. J. Therm. Biol. 78, 219-226. https://doi.org/10.1016/j.jtherbio.2018.09.007

Taha, E.-K.A., Alqarni, A.S. (2013) Morphometric and Reproductive Organs Characters of Apis mellifera jemenitica Drones in Comparison to Apis mellifera carnica. Int. J. Sci. Eng. Res. 4

Tautz, J., Maier, S., Groh, C., et al. (2003) Behavioral performance in adult honey bees is influenced by the temperature experienced during their pupal development. Proc. Natl. Acad. Sci. 100, 7343-7347. https://doi.org/10.1073/pnas.1232346100

Wang, Q., Xu, X., Zhu, X., et al. (2016) Low-Temperature Stress during Capped Brood Stage Increases Pupal Mortality, Misorientation and Adult Mortality in Honey Bees. PLOS ONE. 11 :e0154547. https://doi. org/10.1371/journal.pone.0154547

Wharton, K.E., Dyer, F.C., Huang, Z.Y., Getty, T. (2007) The honeybee queen influences the regulation of colony drone production. Behav. Ecol. 18, 1092-1099. https://doi.org/10.1093/beheco/arm086

Wharton, K.E., Dyer, F.C., Getty, T. (2008) Male elimination in the honeybee. Behav. Ecol. 19, 1075-1079. https://doi.org/10.1093/beheco/arn108

Winston, M.L. (1987) The Biology of the Honey Bee. Harvard University Press

Zhu, X., Xu, X., Zhou, S., et al. (2018) Low temperature exposure $\left(20^{\circ} \mathrm{C}\right)$ during the sealed brood stage induces abnormal venation of honey bee wings. J. Apic. Res. 57, 458-465. https://doi.org/10.1080 /00218839.2017.1412575

Publisher's note Springer Nature remains neutral with regard to jurisdictional claims in published maps and institutional affiliations. 